\title{
EFFECT OF USING LACTOBACILLUS ACIDOPHILUS ON E.COLI CAUSING EMBRYONIC DEATH AND LOW HATCHABILITY IN BALADY HATCHERIES AT DAKAHLIA GOVERNORATE
}

\author{
GHADA A. ABD EL-DAYEM* ${ }^{*}$ and SHEREEN S. MOUSTAFA** \\ * Department of poultry disease, Animal Health Research Institute, Dokki, Giza, Mansoura branch. \\ ** Department of bacteriology, Animal Health Research Institute, Dokki, Giza, Mansoura branch.
}

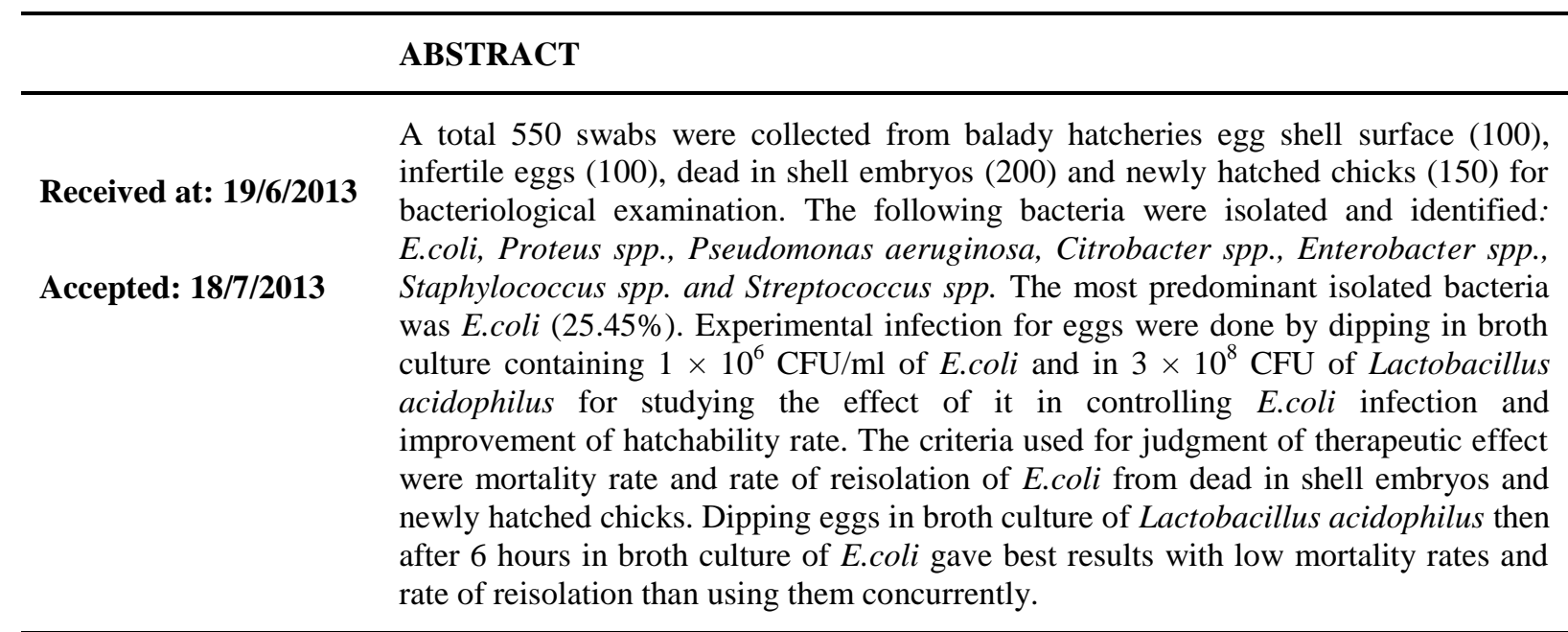

Key words: Embryonic death, L. acidophilus, balady hatcheries

\section{INTRODUCTION}

Bacterial infection of poultry is representing a worldwide important factor in term of their economic losses and public health. Hatchability and the rate of chick survival are one of the major determination factor of productivity in poultry. The hatchery is the greatest source for spread of diseases within the poultry industry. The problem usually starts with contaminated eggs which are incubated under ideal condition for microbiological reproduction. Numerous bacterial pathogens that contaminate hatcheries have been isolated from egg shell, egg content as well as from dead in shell embryos. They included: Salmonella spp., E.coli, Klebsiella spp., Proteus spp. Staphylococcus aureus and Streptococcus (Ibraheem and Abd El-Latif 1997; Walker et al., 2002; Northcutt et al., 2004; Kim et al., 2007; Al-Khalaf et al., 2010 and Kirunda et al., 2010). Poultry bacterial pathogens are mainly controlled by using chemotherapeutic drugs. Unfortunately, the long term and extensive use of antibiotic for veterinary purpose may eventually result in selection for the survival of resistant microbial species (Aarestrup, 1999). Genes encoding for this resistance also can be transferred to other formerly susceptible bacteria, thereby causing a threat to both animal and human health (Montagne et al., 2003). An alternative approach to therapeutic antibiotic is the using of probiotic which means "for life".
It has been defined as a live microbial feed supplement which beneficially affects the host animal by improving its intestinal balance (Fuller, 1989). Two genera of bacteria are most reported as probiotic including lactic acid bacteria of genus Lactobacillus (Higgins et al., 2008; Yegani and Krover, 2008; Sato et al., 2009; Taheri et al., 2009 and Lee et al., 2010) and bifodobacteria (Willis et al., 2010). The effects of some probiotic bacterial were reported, they include modification of the microbial composition and metabolic activity of the intestinal flora, inhibition of infective pathogens like E. coli, Salmonella typhimurium and Staphylococcus aureus by competitive exclusion and enhancing the growth and development indexes in chickens (Reque et al., 2000; Awad et al., 2009; Higgin et al., 2010). (Fuller, 1977) found that host-specific Lactobacillus strains were able to decrease E.coli in the crop and small intestine. (Watkin et al., 1982) Similarly observed the competitive exclusion of pathogenic E.coli occurred in the gastrointestinal tract of gnotobiotic chicks dosed with Lactobacillus acidophilus.

Recent finding indicate that bacteria can be established in the intestine as the embryo develops to stage where the gastrointestinal tract differentiates and close, and the embryo starts ingestion of amniotic fluid (Klasing, 1998). Therefore, probiotic could be introduced into embryonating eggs and established itself as the chick's intestinal microbiota. 
This study was designed to isolate and identify the bacterial pathogens that cause low hatchability rate in balady hatcheries at Dakahlia Governorate and Studying the effect of Lactobacillus acidophilus on controlling these pathogens and improving the hatchability rate.

\section{MATERIALS AND METHODS}

\section{Specimens:}

A total of 550 swabs were collected from balady hatcheries in Dakahlia Province. They include 100 egg shell surface, 100 infertile eggs (yolk), 200 from dead in shell embryos (liver, heart, yolk) and 150 from newly hatched chicks (liver, heart, yolk).

\section{Media required:}

Selective enrichment media: Nutrient broth, Selenite F broth and Heart infusion broth.

Plating solid media: Nutrient agar and blood agar medium.

Characterization media: McConkey's agar, S.S agar, Baird Parker agar and Eosin Methylene Blue agar.

Biochemical media: Triple sugar iron medium, Christen's urea agar medium, Simmon's Citrate agar medium, Indol test medium, Methy red and Voges Proskauer test medium and Sugar fermentation medium containing $1 \%$ of the following sugars. (Dlucitol, glucose, lactose, manitol and sucrose)

\section{Experimental bacterial strains:-}

E.coli: The isolated E.coli streptomycin resistant strain was prepared as described by (Glunder and Siegmann, 1989 and Bisgaard, 1995).

Lactobacillus Acidophilus: It was obtained from Animal Health Research Institute, Dokki, Egypt.

Eggs: A Total of 520 eggs were obtained from Mansoura Poultry Company used for experimental infection.

\section{Methods:-}

Collection and treatment of samples:-

Under aseptic conditions swabs were taken from egg shell surface, yolk of infertile eggs. The surface of unhatched eggs was disinfected using $70 \%$ ethyl alcohol and flamed. The egg shell was broken and the unhatched embryo was removed with sterile forceps and put in sterile petri dish and opened to expose the internal organs. Swabs from yolk, liver and heart put in sterile test tubes containing nutrient broth.

Also Swabs were taken from liver, yolk and heart of newly hatched chicks by inserting bacteriological loops inside internal organs for cultivation, isolation and identification of microorganisms.

\section{Bacterial isolation:-}

Under strict aseptic precautions, the bacteriological samples were inoculated into nutrient and selenite Fbroth and incubated aerobically at $37{ }^{\circ} \mathrm{C}$ for $24-48$ hours and then streaked on nutrient agar, blood agar, MacConkey's agar, S.S. agar, Baird Parker agar, EMB agar and the plates of these media were incubated at $37{ }^{\circ} \mathrm{C}$ for 24 hours, different colonies were picked up from selective media and subcultured on slope agar medium.

Identification of bacterial isolates: Morphological characterization and Gram's stain. The bacterial isolates were biochemically identified according to Finegold and Martin (1982).

\section{Experimental infection:}

This method was done according Zeinab et al. (2011). A total of 520 eggs were used. Twenty of them were examined to establish their freedom from E.coli. The remain 500 egg were divided into 5 groups. Each group contain 100 eggs $(1,2,3,4,5)$ table (1).

Group (1): Eggs were infected by dipping in broth culture containing $1 \times 10^{6} \mathrm{CFU} / \mathrm{ml}$ of E.coli for 15 minutes.

Group (2): Eggs were infected by dipping in broth culture containing $1 \times 10^{6} \mathrm{CFU} / \mathrm{ml}$ of E.coli and $3 \times 10^{8}$ of Lactobacillus acidophilus for 15 minutes.

Group (3): Eggs were infected by dipping in broth culture containing $3 \times 10^{8} \mathrm{CFU} / \mathrm{ml}$ of Lactobacillus acidophilus for 15 minutes then after 6 hours dipped in broth culture containing $1 \times 10{ }^{6} \mathrm{CFU} / \mathrm{ml}$ of E.coli for 15 minutes.

Group (4): Eggs were infected by dipping in broth culture containing $3 \times 10^{8} \mathrm{CFU} / \mathrm{ml}$ of Lactobacillus acidophilus for 15 minute.

Group (5): Eggs were dipped in sterile nutrient broth as a control.

Eggs of all groups were incubated for 21 days at $37^{\circ} \mathrm{C}$ and humidity $60-70 \%$ with daily observation for embryo livability or mortality. Specimens including yolk sac, liver, heart of dead embryos were collected and cultured for bacteriological examination for E.coli re-isolation.

The newly hatched chicks from each group were killed and specimens from heart, liver and yolk were collected and cultured for bacteriological examination for E.coli reisolation. 


\section{RESULTS}

\section{Bacterial isolation:}

Out of 550 samples (100 eggshell, 100 infertile eggs, 200 dead in shell embryos and 150 newly hatched chicks) 220 bacterial isolates were obtained (Table 2). The isolated bacteria were E.coli (56), Proteus spp. (43), Pseudomonas Aeruginosa (33), Citrobacter spp. (22), Enterobacter spp. (26), Staphylococcus spp. (20) and Streptococcus spp. (20). The most predominant isolated bacteria was E.coli $(25.45 \%)$ of isolated bacteria.

\section{Experimental infection:}

The mortality rate of embryonating chicken eggs that infected with E.coli and Lactobacillus acidophilus is shown in table (3). The mortality rate was (52\%) in group (1) that infected by dipping in broth culture of E.coli while it was $(45 \%)$ and $(35 \%)$ in group (2) and group (3) that infected by dipping in broth culture of E.coli and Lactobacillus acidophilus.

Table (4) reveals that the rate of reisolation of E.coli from dead in shell embryos was high in group (1) $(86.53 \%)$ as compared with group (2) (75\%) and group (3) (63.3\%). Also the rate of reisolation of E.coli from newly hatched chicks in group (1) was high $(83.3 \%)$ as compared with group (2) $(74.5 \%)$ and group (3) (57.1\%).

Table 1: Represents experimental infection design.

\begin{tabular}{cccc}
\hline Group No. & * M.O & $\begin{array}{c}\text { No. of } \\
\text { dipping eggs }\end{array}$ & Time of dipping \\
\hline 1 & E. coli & 100 & 15 minutes \\
\hline 2 & E. coli and Lactobacillus acidophilus & 100 & 15 minutes \\
\cline { 2 - 4 } 3 & Lactobacillus acidophilus & 100 & 15 minutes after $6 \mathrm{hr}$ \\
\hline 4 & E. coli & 100 & 15 minutes \\
\hline 5 & Lactobacillus acidophilus & 100 & 15 minutes \\
\hline
\end{tabular}

M.O.: Microorganism

Table 2: Illustrates the results of bacterial isolation from egg shell surface, infertile eggs, dead in shell embryos and newly hatched chicks obtained from balady hatcheries in different areas of Dakahlia Governorate.

\begin{tabular}{|c|c|c|c|c|c|c|c|c|c|}
\hline $\begin{array}{c}\text { Recovery } \\
\text { site }\end{array}$ & $\begin{array}{c}\text { No. of } \\
\text { samples }\end{array}$ & $\begin{array}{c}\text { Total } \\
\text { isolates }\end{array}$ & E. coli & $\begin{array}{c}\text { Proteus } \\
\text { spp. }\end{array}$ & $\begin{array}{c}\text { Pseudomonas } \\
\text { aeruginosa }\end{array}$ & $\begin{array}{c}\text { Enterobacter } \\
\text { spp. }\end{array}$ & $\begin{array}{c}\text { Citrobacter } \\
\text { spp. }\end{array}$ & $\begin{array}{l}\text { Staph } \\
\text { spp. }\end{array}$ & $\begin{array}{c}\text { Streptococcus } \\
\text { spp. }\end{array}$ \\
\hline Egg shell & 100 & 33 & 7 & 6 & 3 & 5 & 3 & 4 & 3 \\
\hline Infertile eggs & 100 & 45 & 10 & 9 & 8 & 5 & 4 & 4 & 5 \\
\hline $\begin{array}{c}\text { Dead in } \\
\text { shell embryos }\end{array}$ & 200 & 85 & 23 & 15 & 13 & 9 & 9 & 8 & 8 \\
\hline $\begin{array}{l}\text { Newly } \\
\text { hatched } \\
\text { chick }\end{array}$ & 150 & 57 & 16 & 13 & 9 & 7 & 6 & 4 & 4 \\
\hline Total & 550 & 220 & 56 & 43 & 33 & 26 & 22 & 20 & 20 \\
\hline $\begin{array}{c}\text { Prevalence of } \\
\text { bacterial } \\
\text { isolates }\end{array}$ & - & - & $25.45 \%$ & $19.55 \%$ & $15 \%$ & $11.82 \%$ & $10 \%$ & $9.09 \%$ & $9.09 \%$ \\
\hline
\end{tabular}

*Percentage compared with total number of isolated bacteria 
Table 3: Shows mortalities of embryonating chicken eggs after dipping in $1 \times 10^{6}$ E. coli and $3 \times 10^{8}$ Lactobacillus acidophilus.

\begin{tabular}{cccccc}
\hline $\begin{array}{c}\text { Group } \\
\text { No. }\end{array}$ & $\begin{array}{c}\text { No. of dipped } \\
\text { eggs }\end{array}$ & ${ }^{* *}$ M.O. & Time of dipping & \multicolumn{2}{c}{ Embryo mortalities } \\
\hline 1 & 100 & E. coli & 15 minutes & 52 & $52 \%$ \\
\hline 2 & 100 & $\begin{array}{c}\text { E.coli and Lactobacillus } \\
\text { acidophilus }\end{array}$ & 15 minutes & 45 & $45 \%$ \\
\hline 3 & 100 & $\begin{array}{c}\text { Lactobacillus acidophilus } \\
\text { hr } \rightarrow \text { E. coli }\end{array}$ & $\begin{array}{c}15 \text { minutes then } \\
\text { after } 6 \text { hr, E. coli } \\
\text { for 15 minutes }\end{array}$ & 30 & $30 \%$ \\
\hline 4 & 100 & Lactobacillus acidophilus & 15 minutes & 9 & $9 \%$ \\
\hline 5 & 100 & Control & 15 minutes & 10 & $10 \%$ \\
\hline
\end{tabular}

*Percentage compared with total number of dipped eggs.

*** M.O.: Microorganism

Table 4: Shows the results of reisolation of E. coli from dead in shell embryos and newly hatched chicks.

\begin{tabular}{ccccccc}
\hline \multirow{2}{*}{$\begin{array}{c}\text { Nroup } \\
\text { No. }\end{array}$} & \multicolumn{2}{c}{ Reisolation from dead in shell embryos } & \multicolumn{3}{c}{ Reisolation from newly hatched chicks } \\
\cline { 2 - 7 } & $\begin{array}{c}\text { No. of dead } \\
\text { embryos }\end{array}$ & $\begin{array}{c}\text { No. of positive } \\
\text { cases }\end{array}$ & $* \%$ & No. of chicks & $\begin{array}{c}\text { No. of positive } \\
\text { cases }\end{array}$ & $* \%$ \\
\hline 1 & 52 & 45 & 86.53 & 48 & 40 & 83.3 \\
\hline 2 & 40 & 30 & 75 & 55 & 41 & 74.5 \\
\hline 3 & 30 & 19 & 63.3 & 70 & 40 & 57.1 \\
\hline 4 & 9 & - & - & 91 & - & - \\
\hline 5 & 10 & - & - & 90 & - & - \\
\hline
\end{tabular}

group (1) = eggs dipped in $1 \times 10^{6} \mathrm{CFU} / \mathrm{ml}$ of $E$. coli

group (2) = eggs dipped in $1 \times 10^{6} \mathrm{CFU} / \mathrm{ml}$ of E. coli and $3 \times 10^{8} \mathrm{CFU}$ of Lactobacillus acidophilus

group (3) = eggs dipped in $3 \times 10^{8} \mathrm{CFU} / \mathrm{ml}$ of Lactobacillus acidophilus and after $6 \mathrm{hr}$ dipped in $1 \times 10^{6} \mathrm{CFU}$ of E. coli

group (4) = eggs dipped in $3 \times 10^{6} \mathrm{CFU}$ Lactobacillus acidophilus

group $(5)=$ control

*Percentage compared with number of examined dead in shell embryos and newly hatched chicks

\section{DISCUSSION}

Hatchery industry considered one of the major steps in poultry production cycles, so must obtained good sanitation and low bacterial contamination that play an important role in lowering hatchability and decreasing the performance of hatched chicks.

In this study we obtained 220 bacterial isolates which were identified as E.coli, Proteus spp., Pseudomonas aeruginosa, Citrobacter spp., Enterobacter spp., Staphylococcus spp., and Streptococcus spp. This result is agreement with (Al-Khalaf et al., 2010 and Kirunda et al., 2010) who could isolated the same bacterial strains from egg shell, infertile eggs, dead in shell embryos and newly hatched chicks.

E.coli is the most prevalent isolate in this study and it was isolated with prevalence of $25.45 \%$ of isolated bacteria. Transmission of avian pathogenic E.coli strains through contamination of incubated eggs or embryo infection has been described (Saif et al., 2003).

(Cortes et al., 2004) reported that the contamination of hatching eggs with E.coli is a major cause of yolk sac infection and the presence of germ on the egg shell increase the risk of omphalitis and shell mortalities.

(Al-Khalaf et al., 2010; Azmy, 2010 and Kirunda et al., 2010) isolated E.coli at a rate of $25.9 \%, 24 \%$ and $27.9 \%$ respectively. While (Shalaby and Abd ElHamid, 1987 and Raji et al., 2007) isolated E.coli from unhatched eggs in prevalence of $44 \%$ and $47 \%$ respectively. In addition, (Abd El- Galil et al., 1984 and Azmy, 1996) isolated E.coli from newly hatched chicks at a rate of $15 \%$ and $62 \%$ respectively.

Proteus spp. was isolated with mean prevalence of (19.55\%). (Fyrouz et al., 2011) reported that Proteus 
reduced hatchability rate into $58 \%$ in embryonated eggs. (Abd El-Latif, 1995 and Al-Khalaf et al., 2010) isolated Proteus from dead in shell embryos with various prevalence. (Abd El- Gawad, 1989 and Azmy, 1996) isolated Proteus from newly hatched chicks.

Pseudomonas aeruginosa was isolated with mean prevalence of $15 \%$. (Walker et al., 2002) suggested that Pseudomonas aeruginosa can invade fertile eggs causing death of embryos and newly hatched chicks. (Karaman, 1980; Al-Khalaf et al., 2010 and Azmy, 2010) isolated Pseudomonas aeruginosa from dead in shell embryos and infertile eggs at a rate of $17.2 \%$, 17.11 and $14.63 \%$ respectively. (Hebat-Allah, 2004) isolated Pseudomonas aeruginosa from dead in shell embryos and newly hatched chicks in percentage of $21 \%$ and $17.6 \%$ respectively.

Moreover, Enterobacter spp. and Citrobacter spp. were isolated at a rate of $11.82 \%$ and $10 \%$ respectively (Abd El-Latif, 1995; Husseina et al., 2008 and Al-Khalaf et al., 2010) isolated them with various prevalence.

Staphylococcus spp. and Streptococcus spp. were isolated with mean prevalence $9.09 \%$ for both of isolated bacteria. (Azmy, 2010) isolated Staphylococcus spp. and Streptococcus spp. from dead in shell embryos at prevalence of $7 \%$ and $3.7 \%$ respectively. Staphylococcus aureus was isolated from newly hatched chicks by (Abd El- Galil et al., 1984 and Azmy, 1996) at prevalence of $14.7 \%$ and $15 \%$ respectively.

Following the discovery that chicks can hatch with bacteria already in their intestine the idea of establishing an intestinal community of healthy bacteria during incubation to make it more difficult for pathogens to establish themselves and cause disease. A suspension of probiotics can be administered in the hatchery as spray into eggs inside incubator, In ovo ( Navid Hossein et al., 2011) and dipping eggs in it (Fyrouz et al., 2011).

In the experimental infection we dipped the eggs in broth culture containing $1 \times 10^{6} \mathrm{CFU} / \mathrm{ml}$ of E.coli which represent the top of isolated pathogens and in broth culture containing $3 \times 10^{8} \mathrm{CFU}$ of Lactobacillus acidophilus as competitive exclusion product against challenge with E.coli.

The embryonic mortality rate was $52 \%$ in group (1) that infected with E.coli by dipping for 15 minutes as compared with $10 \%$ in control group (5). This indicated the responsibility of E.coli for lowering hatchability rate.

This finding assumed the possibility of transmission of E.coli via egg shell penetration. This result supporting the result of (Al-Bahry et al., 2012). The mortality rates were reduced into $45 \%$ and $30 \%$ in group (2) and group (3) that dipped in broth culture of
E.coli and Lactobacillus acidophilus. This result confirm concept of early administration of probiotic in hatchery may help gut maturation, improve gut health and so aid in the prevention of colonization by pathogens such as Salmonella, E.coli and Campylobacter (Helen Houghton, 2011).

The mortality rate was $(45 \%)$ in group (2) that dipped in broth culture of E.coli and Lactobacillus acidophilus concurrently and the mortality rate was $(38 \%)$ in group (3) that dipped first in broth culture of Lactobacillus acidophilus then after 6 hours dipped in broth culture of E.coli. This result agreement with (Fyrouz et al., 2011) who reported that dipping of eggs in broth culture of Lactobacillus acidophilus then after 6 hours eggs dipped in broth culture of Salmonella or in broth culture of Proteus improved hatchability rate than dipping them concurrently.

Comparing mortality rate $(9 \%)$ in group (4) that dipped in broth culture of Lactobacillus acidophilus to the mortality rate (10\%) in group (5) control group we noticed slight improvement in hatchability rate. (Lalev et al., 2011) noticed slight improvement of hatchability rate $(91.29 \%)$ for eggs from broiler breeder feed on probiotics as compared to the control group (91.\%).

The rate of reisolation of E.coli from group (1) that dipped in broth culture of E.coli was higher as compared to groups (2) and group (3) that dipped in broth culture of E.coli and Lactobacillus acidophilus. This result confirm the concept of metabolites produced by Lactobacillus acidophilus have bacteriostatic effects and antimicrobial agents for pathogenic bacteria such as E.coli and Staphylococcus aureus (Amin et al., 2009; Gharaei Fathabad and Eslamifar, 2011and Hassan et al., 2013).

\section{REFERENCE}

Aarestrup, F.M. (1999): Association between the consumption of antimicrobial agents in animal husbandry and the occurrence of resistant bacteria among food animals. Int. J. Antimicrob. Ag., 12: 279-285.

Abd El-Gawad, A.A. (1989): "Some studies on Proteus infection in chickens". M.V.SC. Thesis, Poult. Dis. Fac. Vet. Med. Assuit University.

Abd El-Latif, M.M. (1995): "Bacterial Causes of lowering fertility, hatchability and early embryonic deaths in balady hatcheries in Dakahlia Governorate" M.V.SC. Thesis (Microbiology), Fac. Vet. Med. Zagazig University.

Abd El-Galil, Y.; El-Bakry, M. and Ammar, A. (1984): Bacterial Causes of early chicks 
mortalities in Sharkia Governorate". Procceding of 17 world Poultry Congress Helsinki 557.

Al-Bahry S.N.; Mahmoud, I.Y.; Al-Musharafi, S.K. and Al- Ali, M.A. (2012): Penetration of spoilage and food poisoning bacteria into fresh chicken egg: A public health concern. G.J.B.B., Vol. 1(1): 33-39.

Al-Khalaf, A.N.; Akeila, M.A.; Al-Dubaib, M.A.; Azzam, A.H.; El-Shafey, A.A. and Draz, A.A. (2010): Bacterial contamination of hatcheries. Journal of Agricultural and Veterinary Sciences, Qassim University 2 (2): 67-76.

Amin, M.; Jorfi, M.; Khosravi, A.D.; Samarbafzadeh, A.R. and Sheikh, A.F. (2009): Isolation and identification of Lactobacillus Casei and Lactobacillus plantarum from plants by PCR and detection of their antibacterial activity. J. Biol. Sci, 9: 810-814.

Awad, W.A.; Ghareebk,; Abdel-Raheems and Bohm, J. (2009): Effects of dietary inclusion of probiotic and symbiotic on growth performance, organ weights and intestinal histomorphology of broiler chickens. Poult. Sci. 88: 49-55.

Azmy, E.M. (1996): "Study on Some bacterial Causes of early chick mortalities in Sharkia Province M.V.SC. Thesis, (Poultry Diseases), Fac.Vet.Med. Zagazig University.

Azmy, R.W. (2010): Some studies on bacterial Causing embryonic mortalities in chickens and ducks. M.V.SC., Thesis (Poultry Diseases), Faculty of Veterinary Medicine, Zagazig University.

Bisgaard, M. (1995): Salpingitis in Web-Footed birds: prevalence, etiology and Significance, Avian Pathology, 24: 243 - 452.

Cortes, C.R.; Isaies, G.T.; Cuello, C.L.; Floes, J.M.V.; Anderson, R.C. and Campos, C.E. (2004): Bacterial isolation rate from fertile eggs, hatching eggs and neonatal broilers with yolk sac infection. Rev. Latinoamericana de Microbiologia, 46: 12-16.

Finegold, S.M. and Martin, W.J. (1982): "Bailey and Scott, Diagnostic Microbiology" $6^{\text {th }}$ Ed. The C.V. Mosby Company, St. Louis, Toranto, London.

Fuller, R. (1977): The importance of Lactobacilli in maintaining normal microbial balance in The crop. Br. Poult Sci., 18, 85-94.

Fuller, R. (1989): Probiotics in man and animals. J. Appl. Bacterial. 66, 365-378.

Fyrouz, A.M.; Hassan Eman, R. and Rabiee Nagwa, $S$. (2011): Studies on pathogens causing low hatchability in eggs and the effect of Lactobacillus Acidophilus on controlling of Salmonella Typhimurium and Proteus. Report and Opinion: 3(2) 8-13.
Gharaei-Fathabad, E. and Eslamifa, M. (2011): Isolation and applications of one strain of Lactobacillus paraplantarum from tea leaves (Camellia Sinensis). Am. J. Food Technol., 6: 429-434.

Glunder, G. and Siegmann, O. (1989): Occurance of Aeromonas hydrophila in wild birds.Avian Patholo.18: 685-695.

Hassan Pyar; Min-Tze Liong and Peh, K.K. (2013): Characteristics and Antibacterial Activity of Metabolities from Lactobacillus acidophilus strains Produced from Novel Culture media. International Journal of Pharmacology. 9 (1): 92-97.

Hebat-Allah M. Mohamed (2004): Some Studies on Pseudomonos species in chicken embryos and broilers in Assiut Governorate. Ass. Univ. Bull. Environ. Res., Vol. 7, No. 1.

Helen Houghton (2011): Disease prevention in the chick embryo and young chick. Nuffield farming scholarships Trust ABEMB (R and E) Trust Award.

Higgins, J.P.; Higgins, S.E.; Wolfenden, A.D.; Henderson, S.N.; Torres-Rodriguez, A.; Vicente, J.L.; Hargis, B.M. and Tellez, G. (2010): Effect of lactic acid bacteria Probiotic culture treatment timing on Salmonella entritidis in neonatal broilers. Poult. Sci. 89: 243-247.

Higgins, S.E.; Higgins, J.P.; Wolfenden, A.D.; Henderson, S.N.; Torre. Rodriquez, A.; Tellez, G. and Hargis, B. (2008): Evaluation of a Lactobacillus based probiotic culture for the reduction of Salmonella enteritis in nenonatal broiler chicks. Poul. Sci., 87: 27-31.

Husseina, S.A; Hassanb, A.H. and Sulaimanc, R.R. (2008): Bacteriological and Pathological study of yolk Sac infection in broiler chicks in Sulmani District. J. Dohuk Univ. Vol. 11, No. 1: $48-56$.

Ibraheem, O.K. and Abd El -Latif, A. (1997): Studies on some bacterial agents isolated from dead in shell chicken embryos and baby chicks in Sharkia Province. J. Egypt. Vet. Med. Ass. 57 (1): 747 .

Karaman, R.A. (1980): Studies on some bacterial diseases of poultry causing high mortality in balady hatcheries in Monofia Province M.V.SC., Thesis (Poultry Diseases), Faculty of Veterinary Medicine, Cairo University.

Kim, A.; Lee, Y.J.; Kang, M.S.; Kwag, S.I. and Cho, J.K. (2007): Dissemination and tracking of Salmonella spp. in integrated broiler operation. J. Vet. Sci. 8 (2): $155-61$.

Kirunda, H.; Muwereza, N.; Kasaija, P.D.; Kerfua, S.D. and Kumonyol, K. (2010): Infectious and non infectious factors affecting hatchability in indigenous chickens in Eastern Uganda. Africa 
Journal of Animal and Biochemical Sciences 5 (3): 51-59.

Klasing, K.C. (1998): Digestion of food. Pages 36-70 in Comparative Avian Nutrition. Cab International, Walling ford, UK.

Lalev, M.; Magdalena Oblakova; Pavlina Hristakieva; Nadja Minceva and Ivaniva Ivaniva. (2011): Investigation of dietary probiotic effects on productive traits in broiler breeders. Archiva Zootechnica 14: 2, 57-65.

Lee, K.; Lilleho, H.S. and Siragusa, G.R. (2010): Direct fed microbials and their impact on the intestinal microflora and immune system of chickens. J. Poul. Sci., 47: 106-114.

Montagne, L.; Pluske, J.R. and Hampson, D.J. (2003): A review of interactions between dietary fibre and the intestinal mucosa and their consequences on digestive health in young non ruminant animals. Anim. Feed Sci. Technol. 103, 95-117.

Navid Hossein-Mansoub; Tohid vahdatpour; Mohammed Arjomandi and Sina Vahdatpour. (2011): Comparison of different methods of probiotic prescription against Salmonella infection in hatchery broiler chickens. Advances in Environmental Biology, 5 (7): 1857-1860.

Northcutt, J.K.; Jones, D.R.; Ingram, K.D.; Hinton, A.J. and Musgrove, M.T. (2004): Air borne rnicroorganisms in Commercial shell egg processing facilities. International Journal of Poultry Science, 3 (3): 195.

Raji, M.A.; Kwaga, J.O.; Bale, J.O. and Henton, M. (2007): Serovars and biochemical characterization of E.coli isolated from colibacillosis cases and dead in shell embryos in poultry in Zaria-Nigeria. Veterinarski Arhiv., 77 (6): 495-505.

Reque, F.E.; Pandey, 1.; Franco, S.G. and Soccol, C.R. (2000): Isolation, Identification and physiological study of Lactobacillus fermentum LBP for use as probiotic in chickens. Braz. J. Microbiol. 31: 303: 307.

Saif, Y.M.; Barens, H.J.; Fadly, A.M.; Gilsson, J.R. and Swayne, D.E. (2003): poultry Disease, $11^{\text {th }}$ Ed., Iowa State Press, Iowa

Sato, K.K.; Takahashi, M.; Tohno, Y.; Miura, T.; Kamada, S. Ikegami and Tazawa, H.K. (2009): Immunomodulation in gut- associated lymphoid tissue of neonatal chick by immunobiotic diets. Poult. Sci. 88: 2532-2538.

Shalaby, N.A. and Abd El-Hamid, H.S. (1987): Microbial agents responsible for embryonic mortalities in hatcheries in Gharbia Province. Zagazig Vet., J. X V (2): 165.

Taheri, H.R; Moravej, H.; Tabandeh, F.; Zaghari, M. and Shivazad, M. (2009): Screening of lactic acid bacteria toward their selection as a source of chicken probiotic. Poult. Sci., 88: 1586-1593.

Walker, S.E.; Sander, J.E.; Cline, J.L. and Helton, J.S. (2002): Characterization of Pseudomonas aeruginosa isolates associated with mortality in broiler chicks. Avian Dis. 46: 1045-1050.

Watkins, B.A.; Miller, B.F. and Neil, D.H. (1982): In vivo effects of Lactobacillus acidophilus against pathogenic Escherichia coli in gnotobiotic chicks. Poult. Sci. 61: 1298-1308.

Willis, W.L.; Isikhuemhen, O.S.; Minor, R.C.; Hurley, S. and Ohimain, E.I. (2010): Comparing the feeding of fungus Myceliated grain with other anticoccodial control measures on oocyst excretion of Eimeria challenged broiler. Int. Poult. Sci., 9 (7): 648-651.

Yegani, M. and Krover, D.R. (2008): Factors affecting intestinal health in poultry. Poult. Sci., 87: 2052-2063.

Zeinab, M.S.; Mahgoub, K.M.; Nagwa, S.R.; Sahar, A.Z. and Kutkat, M.A. (2011): Pathogenicity of Aeromonas on embryonated chicken eggs. Life science Journal, 8 (1): 502-507.

\section{تأثير استخدام اللاكتوباسيلس اسيدوفيلس على بعض أنواع البكتيريا المسبية لنفوق أجنة البيض وانخفاض معدل الفقس في المفرخات البلاية بمحافظة الاقهلية}

\section{غادة علام عبل الد/يم ، شئين سامي مصطفى}

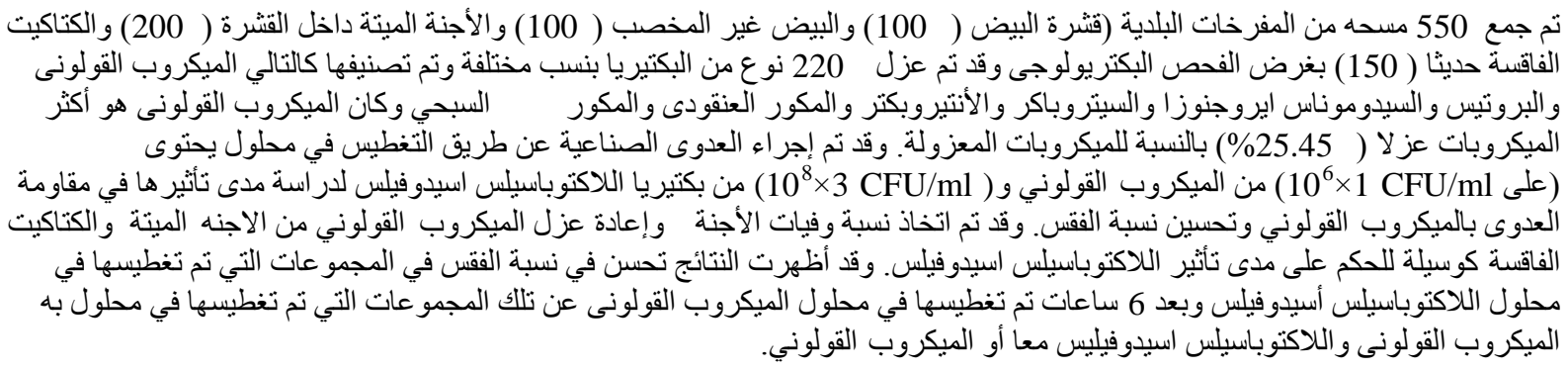

